\title{
Implementation of context-based vocabulary teaching method in Turkish language instruction for foreigners
}

\author{
Neşe Kara Özkan a * (iD), Muammer Nurlu ${ }^{\mathrm{b}}$ \\ ${ }^{a}$ Gazi University, Institute Of Educational Sciences, Ankara 06500, Turkey \\ ${ }^{b}$ Gazi University, Faculty of Education, Ankara 06500, Turkey
}

\section{APA Citation:}

Kara Özkan, N., \& Nurlu, M. (2019). Implementation of context-based vocabulary teaching method in Turkish language instruction for foreigners. Journal of Language and Linguistic Studies, 15(3), 1139-1154.

Submission Date: 07/04/2019

Acceptance Date: 17/07/2019

\begin{abstract}
In the basis of learning a new language, lies the person's understanding of what s/he hears or reads and ability to express him/herself in that language well. Therefore it requires speakers have an extensive vocabulary to communicate with other people effectively, hence vocabulary has an essential position in learning a foreign language. In this research, the effect of context-based vocabulary teaching implementation in instruction of Turkish as a foreign language was studied and experimental and control groups of B2 grader participants were studied with. Experimental group had context-based vocabulary education while control group was given traditional education. This study is a mixed designed research in which quantitative examination methods were used in company. In qualitative studies, documental analyses were made on sentences that participants' predictions about word meaning were involved, and in quantitative version of the study experimental research was made. Pre-tests and post-tests were practiced on groups. Data of pre and post-tests that were made to compare the groups' vocabulary levels were analyzed with Mann Whitney-U Test, and to evaluate the alteration of both groups in themselves, Wilcoxon Signed Rank Test. It was observed that both of the groups were in close levels to each other at pre-test, and lexical gain of experimental group was far more bigger than control group at post-test. At the end of the research, it is deduced that context-based vocabulary teaching method is an effective way of vocabulary teaching in instruction of Turkish as a foreign language.
\end{abstract}

(C) 2019 JLLS and the Authors - Published by JLLS.

Keywords: Context-based vocabulary teaching method; vocabulary teaching in Turkish as a foreign language; vocabulary.

\section{Introduction}

During the history, communication has been the most known and the oldest phenomenon about human. Humans have always been in need of communication from ancient times up to now. They have tried several ways to achieve it. It is known that humans first told their thoughts and wishes to each other with pictures they drew on the cave walls. In the course of time verbal language has been formed with

\footnotetext{
* Neşe Kara Özkan. Tel.: +0-382-217-1330
}

E-mail address: ns_kr@hotmail.com 
words composed of voices and sounds. Written language is formed much later than oral language. Different languages have been used among people living in different parts of the world.

In terms of the "language" concept that is identified in tens of definitions, while the languages other than mother tongue, were learned previously by elite communities for the reasons such as politics, trade, culture etc., learning a foreign language has become an important sector in the 20th and 21st centuries (Erdem, Gül, Şengül and Şimşek, 2015). Today, with developing technology, the time and distance limits on communication have been disappeared. One can communicate with a person face to face, orally or in writing via the internet on his/her computer/mobile phone in anywhere of the world. For this to happen, a common language is required. People can communicate through this language.

People have desire for learning a foreign language for various reasons. The leading factors are to work in a foreign country, to study, wanting to live in a different country depending on personal preferences and the reasons such as having to live in a foreign country because of the difficult conditions in his/her country (war, famine, economical crisis etc.) Individuals who live in a foreign country must learn the language of that country, no matter what their reason to immigrate was because now he/she him/herself has become a part of that country and cannot live apart from it. People must learn the language of that country in order to communicate with other people and understand them while shopping in everyday life and express themselves at least in public life areas. There are language courses, foreign language learning programs offered for foreigners on the internet and story books arranged by levels for this. In Turkey, teaching Turkish to foreigners have been carried out by the institutions within the universities such as TÖMER (Turkish Education Center), private courses, Yunus Emre Institute that conduct studies in order to teach Turkish culture in and out of the country; language teaching sets published by these institutions, books and from the sources such as interactive language teaching programs.

The basis of learning a foreign language is the vocabulary education. There are many languages in the world. People who want to learn a language must learn the sounds of that language and how these sounds are pronounced first. For example, the letter "a" is pronounced as "e" in English. The person who knows the sounds needs to learn the words in target language. Words are the smallest meaningful structures in a language. The objects, concepts and actions have different meanings in different languages. For example; the Turkish word "masa" corresponds to "table" in English, "der tisch" in German, "table" in French, "tavila" in Arabic and "stol" in Russian. The most important point to focus on here is the need to learn the most used words in that language. Especially, the foreigners who learn the most common words will have come a long way in language learning. For this purpose, foreign language teaching should be based on the word frequency studies done.

Emotions, thoughts and requests are transferred from one person to other people by means of the vocabulary. The richer one's vocabulary in a foreign language gets, the more $\mathrm{s} /$ he gains the ability to express him/herself and understand others. Basic level students are first taught the names of the things that are found in their close surroundings and the verbs such as "to open", "to close", "to sit", "to go", "to come" and "to laugh" which can be demonstrated. Later on, abstract concepts, the side and metaphoric meanings of the words are studied on. In the framework of Common Recommendations for European Languages, it is seen that level B2 and $\mathrm{C} 1$ words have many kinds of semantic relations beside their basic meanings (Uzdu Yıldız, 2013).

While teaching words in a foreign language, one of the most important tools is the text. Texts to be used for teaching Turkish to foreigners should be appropriate for the target learners' level and the objectives of the main course. The text must contain the structures that exemplify the subject of grammar which are expected to reflect daily life sections of students and to exemplify Turkish in the best way. 
Also, literary texts enable the person to perceive the language in its natural structure. Hence texts that improve vocabulary are essential tools for advanced level students (Demir and Açık, 2011).

\subsection{Literature review}

The method in teaching a foreign language is a learning element that will deliver the student the fastest and the most reliable way for the purpose of the education. Although many teaching and learning methods have been developed to the present day, there is no real and sufficient method exists. (Memiş and Erdem, 2013). There are many methods for teaching vocabulary in foreign languages and contextbased vocabulary teaching method is one of them as well.

In the Turkish Dictionary (TDK, 1998), the context is defined as "the unit or the units that surround a language unit, affecting the latter or previous units in many cases and determine its meaning and value." According to Yaman and Akkaya (2012) concept is "to provide a linguistic element - it can be words/group of words, sentence, paragraph, even a text- to be evaluated in a wider meaning integrity than itself and the linguistic data based on the relation between part and whole." Context based vocabulary teaching is a method that the meaning of a word is derived from the context in which it is used. While using the context based vocabulary teaching method, it is aimed to teach and understand the words through context (Duran and Bitir, 2017 reporting from McCarten).

Context based vocabulary teaching is done through the text which is being handled or according to the place and function of the words that the students say that they encounter for the first time (Göçer, 2015). To be able to talk about the context in an expression, firstly its grammar structure and meaning dimension should be examined. In order to benefit from context, we need to study on both grammatical (affix, root, word type) and semantic meaning of the word/words, the sentences formed by these words and the other sentences which come before and after this sentence when needed.

In Turkish, words are not limited to only one meaning. They gain meaning in the sentence through their connection with other words or their usage. Although a student knows the meaning of a word, s/he may have difficulty in using that word in a sentence. The underlying reason of this situation is that the words have been taught him/her by being abstracted from their contexts. While teaching the word meanings, the words shouldn't be given only the equivalence in their native language but also the use of these words in a sentence should be taught by showing the meaning gained from the context. Thus, the student will know the word by seeing which words it is used with and what affixes it takes (Tanin, 2004: 73).

The meaning of a word in a sentence and its meaning in another sentence may be different. For example, the word "eye" has more than one meaning.

Tears fell out of eyes. $($ Eye $=$ Sight organ $)$

I should eye over the homework. $($ Eye over $=$ review $)$

We lived for years in two-eye house. $($ Two-eye $=$ two rooms)

He is looking on the car with the eyes of purchaser. (Eyes of purchaser= with intent to buy)

Let's go to the eye of the river. (Eye of river $=$ spring of the river)

I can't see eye of the bead. (Eye of the bead= hole of the bead)

I forgot my notebook on eye of the table. (Eye= drawer)

Seller put lemons on the eye of the scale. $($ Eye of scale $=$ scale pan)

Baby is touched by an evil eye. (Eye= look)

Don't touch the eye of pustule. (Eye of pustule $=$ points of some pustules) 
Pear tree will be vaccinated on the eye of it. (Eye of a tree=a part of the tree which buds out)

You can see eleven examples of different meanings for the word "eye" above. This shows that words gain different meanings depending on contexts and have more than one signification. Therefore, it is not enough to say that eye means organ of sight to learners of Turkish as a foreign language. More precisely, the basic signification of the word "eye"-organ of sight- can be given to beginners by using visuals and in upper levels other meanings can be taught in contexts.

If an unknown word takes place in a text containing familiar words, the meaning of the unknown one can be inferred (Hycraft, 1993: 47). It is necessary to have a rich vocabulary to be able to guess the meaning of a new word by making inferences because the familiar words enable to get the general meaning of the sentence and the new word will be discovered thanks to this context. Besides, rich vocabulary is needed to have enough grammar knowledge. In order to get the signification of the new word, it is important to know its pronunciation, affixes, word types and the phrases that support or change the meaning of the sentence. All these items of information are important factors to infer the definition of the new word. For example, when it is supposed that the unknown word is "exhausted" in the sentence "The child does not want to go to school because he is sick and exhausted." the reader needs to understand the reason of not wanting to go to school is being sick and exhausted. In other words, it is necessary to understand the existence of cause and effect relation. The effect is to want not to go to school and the cause is being sick and exhausted. The words "sick" and "exhausted" are in noun forms and there is a semantic relation between these two. Exhaustion is being tired because of sickness. A reader can deduce the meaning of unknown word "exhausted" by establishing cause and effect relations in the sentence and by considering the semantic relation between these words. In order to achieve that, one needs to have basic knowledge in target language. In respect thereof, İnce (2013) asserted that it is not much possible to use context-based approach in word teaching in foreign language education at A1, A2, and B1 levels. Therefore, it is more proper to apply context-based word teaching to learners in B2 and upper levels. Learners need to have enough grammar and vocabulary knowledge in order to obtain the meaning of the unknown by using the known things.

In foreign language education, it is not possible sometimes to provide an exact meaning of a word in target language. In this case, translation of the definition of that word in source language will be given. With context-based word teaching method, learner will profit by the context and the context implicates him/her the definition. In this way there will be no need to look at another source to get the meaning.

It is more beneficial to learn new words from meaningful sentences rather than looking at dictionaries (Karatay, 2004: 23). If the word has more than one meaning, all of them are given in dictionaries and in order to decide which one is the proper, it is necessary to understand the meaning of the sentence in any case. In other words, in order to get the correct meaning, it is needed to comprehend the sentence. Moreover, it is seen that the word is used in a sentence in dictionaries after giving the meaning of it. The reason of this is to show how it is used in a sentence and to exemplify what it expresses.

In order to derive the meaning of a word from the context it is necessary to make plenty of readings in target language besides having grammar and vocabulary knowledge. It will be easy for learners to understand the grammar structure of target language and to see the semantic relations among lexical items by making readings thanks to encountering known words. In this way it will become possible to get the meaning of new word. Moreover, readings in target language provide permanent learning by repeating the words that were learnt recently. In learning Turkish as a foreign language, reading Turkish books that were prepared according to learners' levels and interests will enable them to improve their vocabulary and increase their interests. 


\subsection{Research questions}

The problem sentence of this research is:

"What is the effect of context-based vocabulary teaching on vocabulary learning in teaching Turkish as a foreign language?" It is purposed in this research to determine the effect of context-based vocabulary teaching method in teaching Turkish as a foreign language.

\subsection{Literature perspective}

Söylemez (2001), made his study, in which he researched the effect of context-based and noncontextual vocabulary teaching methods on vocabulary teaching, with his intermediate students in English preparation class. He concluded that the context-based method has an important effect on students' vocabulary learning and understanding of what they read.

Ortapişirici (2007), examined the success of vocabulary substantivity of students in learning a foreign language (English) by comparing with those who learn the words by deriving the meanings of the unknown words in context and those who learn words with their meanings directly. In conclusion, students that used the deriving word meanings from context method were more successful in vocabulary compared to the students that learn words with meanings directly.

Bora (2013), studied with preparation class (English) students in his study in which he researched the effect of deriving words from context on improving the active vocabulary. In the research that includes the experimental and control groups, it was seen that the students who learn the words by using context-based methods were able to recall and use those words in written expressions more actively.

Gür (2014) revealed in his research that context-based vocabulary teaching method is more effective (based on success) comparing to traditional methods in which he studied on usage of context-based vocabulary teaching method for 3rd graders in primary school.

Duran and Bitir (2017) made a study with 4th graders in primary school to reveal the effect of context-based vocabulary teaching method on gaining vocabulary and concluded that the mentioned method has a significant effect on vocabulary permanence.

Although there are plenty of researches on teaching Turkish as a foreign language, there are no scientific researches that have been made about vocabulary teaching with this method. It is thought that this study is going to make a significant contribution about learning vocabulary in instruction of Turkish as a foreign language. The study is important because it requires students to be active in vocabulary teaching process and gain the word meanings by using their former knowledge which is a helpful way to ensure the persistency of the word meanings.,

\section{Method}

\subsection{Research design}

This study is a mixed designed research in which qualitative and quantitative examination methods were used in company. Experimental design is used among quantitative examination designs for this study. Experimental research is the study that tests the effects of differences formed by researcher on dependent variables. In experimental research, the main aim is to test the cause and effect relations among factors (Büyüköztürk, Kılıç Çakmak, Akgün, Karadeniz \& Demirel, 2013: 195). It is an interventional-experimental research made with random design of pre-test post-test control and experimental groups. Document analysis which is a qualitative examination method was used to promote the data that have been obtained from quantitative examination design. 


\subsection{Population and sample}

The population of the research is B2 grader foreign students who received education at University of Aksaray Turkish Education Implementation and Research Center in 2017-2018 academic years. Sample is 32 of B2 grader foreign students who educated at the same center. Sample was constituted with criterion sampling method of purposeful sampling methods. Purposeful sampling is a non-random sampling method. This method is used in special cases needed to be met certain criterion depending on the purpose of the study or having certain features. According to the criterion sampling method, observation units can be composed of individuals, events, objects or cases having certain criteria. The units that meet the determined criteria are included to the sample (Büyüköztürk et al., 2013: 91). In this study used mentioned sampling method, there are 16 participants in experimental and control groups.

\subsection{Instruments}

For the identification of the participants' personal characteristics, personal information form was used. The reading text (First Step to Moon) received from Turkish for Foreigners 2 CD of Gazi University Turkish Education Implementation and Research Center and pre and post-test forms that have been prepared based on this text were used to determine the vocabulary levels. 3 different domain experts' opinions were taken in preparation of pre and post-tests and the election of the reading text. This "First Step to Moon" titled text was arranged based on B2 level in communicational language proficiency levels of Common European Framework of Reference for Languages. Besides, student practice sheets were used as a data collection tool to examine the meanings of words that were predicted and derived from context by participants.

25 target words were determined from the text before the implementation. These words are the vocabulary that will be taught in context-based method. Test-retest method was used to provide the reliability of the study. In this method, the test was applied the same group in two times regularly. At the end of the applications, the correlation between the scores, product- moment correlation coefficient was calculated. The attained score gives the reliability of the test. The correlation of coefficient calculated in this way shows how stable the scores obtained from two applications. That the correlation coefficient closes to 1 , shows the scores of participants in two tests are similar; that the correlation coefficient closes to 0 , shows the scores are different. A high correlation shows both the stability of test score and that the tested variable didn't change much in time. And low correlation shows the instability of the test or/and inadequacy of the criteria that is tested in the study (Büyüköztürk et al., 2013: 113). The correlation coefficient for reliability analysis is 0.95 , which is a high value. Accordingly, it is possible to say that the reliability of the test is high.

\subsection{Data collection procedures}

The research done to investigate the effects of context based word teaching method on word learning of foreigners in Turkish teaching was conducted with foreign pupils in B2 level. Because the meanings of new words will be derived from the context, it is necessary for participants to know Turkish at least at intermediate level. Because of that, the sample of the study is consisting of foreign learners at B2 level.

The study is conducted with experimental and control groups. In each group, there are 16 foreign students at B2 level. It is determined that the results of both experimental and control groups' pre-tests are close to each other. After analyzed the results of the pre-tests, 5 words are excluded from prepared 25 words because it is determined that some of these words are known by participants and some of them are too difficult to derive meanings from the context. 
The experimental group was taught by using context based vocabulary teaching method for 4 weeks ( 2 hours a week). In the text prepared as a data collection tool, first step of human to the Moon has been told. Therefore, the text includes unfamiliar lexical items for daily life. The researcher prefers it intentionally. The purpose is to provide that the participants can derive the meaning of new word from the context, so it is paid attention to choose unknown words. Throughout 4 weeks working with experimental group, the text has been covered part by part and especially it is dwelled on new word categories. It is necessary to know if those words are nouns or verbs. In the next step the words, words that are close to target word in the sentence have been worked on because these words are clues for the new word. Words attain meanings in sentences. The meaning is formed by relations of the word with other words. In some cases, the sentence can be insufficient to get the meaning of the word. In such cases, we need to look at prior or latter sentences. In these sentences there can be references to the unknown words. At the end of these analyzes participants are asked to write their predictions about the signification of the word on their worksheets. The worksheets are studied by the researcher by using content analysis.

While the experimental group is taught by using context based vocabulary teaching method, in the control group, the meanings of the words are given to participants by the researcher. In other words, in the control group, the participants have asked the unknown words to the researcher and the researcher has given answered them orally and as written.

Two weeks after the implementation, conducted on experimental and control groups throughout four weeks, the post-tests have been applied. The assessment about the effects of context based word teaching method on vocabulary learning has been done.

\subsection{Data analysis}

The pre-tests were applied to both experimental and control groups at the beginning of the research and the data have been analyzed by use of Mann-Whitney U Test on SPSS program. 3 weeks after the implementation, the post-tests were applied to participants. The post-tests' results have also been analyzed by use of Mann-Whitney U Test. The post-tests were applied in order to compare the two groups. The data of pre and post-tests were analyzed by means of Wilcoxon Signed Ranks Test to observe inner groups-improvement. Moreover, in order to determine if participants can derive the meanings from the context or not; or to what extent they get the meanings of the words from the context, the researcher has analyzed the worksheets by using content analysis method.

\section{Results and discussion}

In this part, findings that we have reached in consideration of information which were gained as a result of research and comments related to them are given. First of all, findings acquired from the results of pre-test and post-test of control and experimental groups are given. 
Chart1. Comparison of control and experimental groups' pre-test and post-test results

\begin{tabular}{|c|c|c|c|c|c|c|}
\hline Tests & Groups & $\mathrm{N}$ & $\begin{array}{l}\text { Mean } \\
\text { Rank }\end{array}$ & $\begin{array}{c}\text { Sum of } \\
\text { Sequence } \\
\text { Values }\end{array}$ & $\mathrm{Z}$ & $\mathrm{P}$ \\
\hline \multirow{3}{*}{ Pre Test } & $\begin{array}{c}\text { Experimental } \\
\text { Group }\end{array}$ & 16 & 17,50 & 280,00 & \multirow{3}{*}{$-0,615$} & \multirow{3}{*}{0,539} \\
\hline & $\begin{array}{l}\text { Control } \\
\text { Group }\end{array}$ & 16 & 15,50 & 248,00 & & \\
\hline & Total & 32 & & & & \\
\hline \multirow{3}{*}{ Post Test } & $\begin{array}{c}\text { Experimental } \\
\text { Group }\end{array}$ & 16 & 23,81 & 381,00 & \multirow{3}{*}{$-4,433$} & \multirow{3}{*}{0,000} \\
\hline & $\begin{array}{l}\text { Control } \\
\text { Group }\end{array}$ & 16 & 9,19 & 147,00 & & \\
\hline & Total & 32 & & & & \\
\hline
\end{tabular}

In the chart above, sequence values acquired in accordance with marks, which control and experimental groups got in pre-test held before implementation and in post-test held after implementation, are given. Because of the rarity of observation quantity, non-parametric tests were practiced on. The data were analyzed with Mann Whitney U Test to observe the difference between experimental group and control group. When the result of pre-test considered, we see that the sum of sequence values of experimental group is 280 and the mean rank is 17,50. When it comes to control group's pre-test results, the sum of sequence values is 248 and the mean rank is 15,50. As p=0,539, when results taken in pre-test are observed, there isn't a meaningful difference between control and experimental groups. This situation shows that the groups are equal to each other before practicing with context-based vocabulary teaching.

When the post-test results of control and experimental groups are observed, the sum of sequence values of experimental group is 381 and the mean rank is 23,81 . According to the post-test result of control group, the sum of sequence values is 147 and the mean rank is 9,19. Checking out the sum of sequence values, experimental group is much higher than control group. Also mean rank of experimental group is higher than control group. Besides this as $\mathrm{p}=0,000$ there is a meaningful difference between control group and experimental group in post-test results.

In conclusion of the examinations on sum of sequence values and mean rank; although there wasn't observed an important difference between control and experimental group, after the post-test vocabulary learning level of experimental group participants practiced with context-based vocabulary teaching method was far higher than the control group. 
Form1. Comparison of pre-test and post-test results

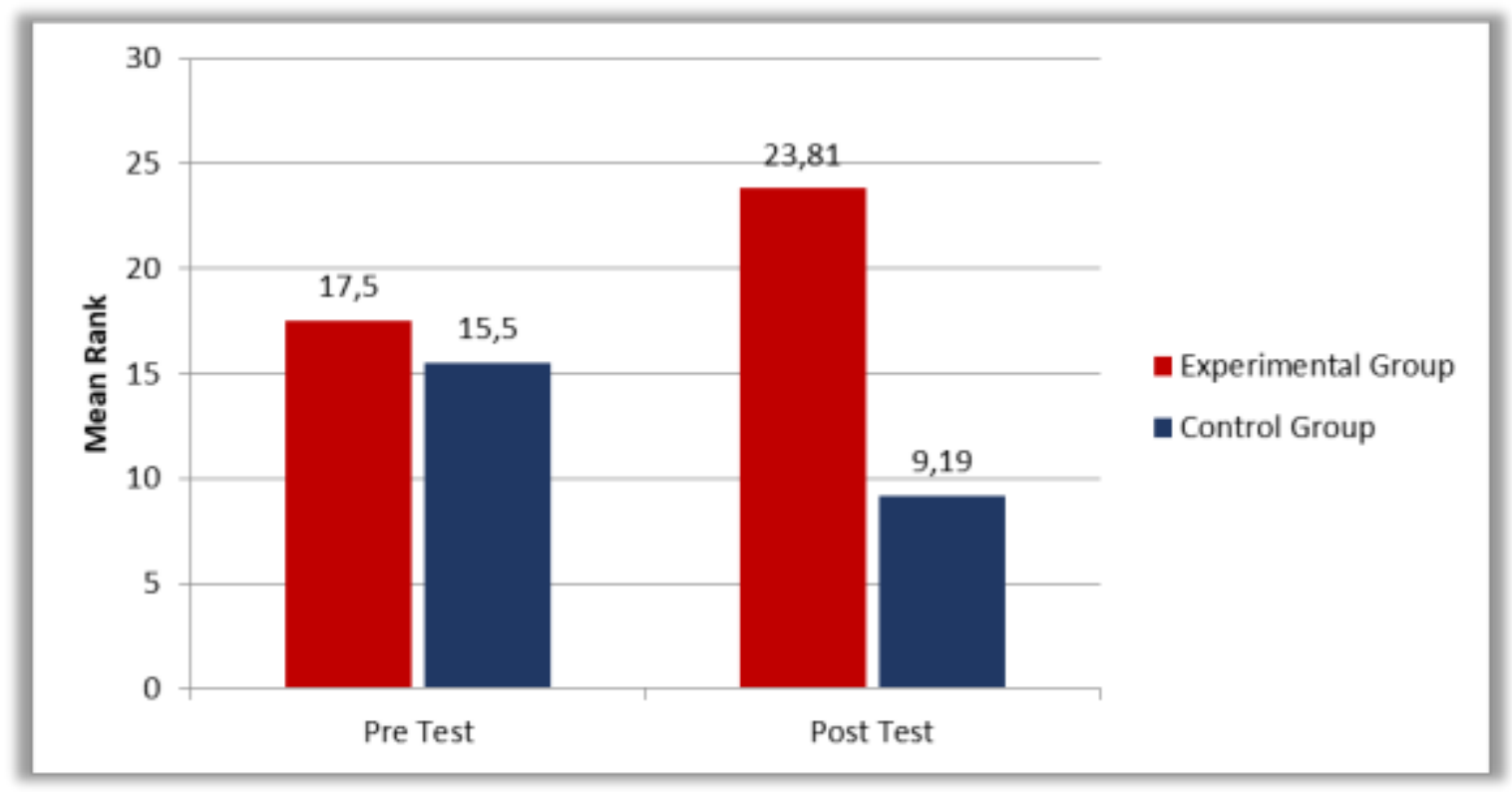

The graphic above was created for data to be more comprehensible. In this graphic, the sum of sequence values that were taken according to the results of pre-test and post-test of control and experimental group were given. Looking at the mean rank in pre-test, we see that experimental group is 17,5 and control group is 15,5 . In this column in graphic, we see that both groups' vocabulary levels are very close to each other. When the graphic showing the post-test results is observed, we see that the sums of sequence values of experimental group is 23,81 and the control group is 9,19 . Data received from the post-test reveal that the level of vocabulary learning of experimental group is much higher than the control group.

Chart2. Comparison of pre-test - post-test results of experimental group

\begin{tabular}{cccccccc}
\hline Groups & Tests & Ranks & N & Mean Ranks & $\begin{array}{c}\text { Sum of } \\
\text { Ranks }\end{array}$ & Z & P \\
\hline \multirow{2}{*}{$\begin{array}{c}\text { Experimental } \\
\text { Groups }\end{array}$} & $\begin{array}{c}\text { Post Test } \\
\text { Pre Test }\end{array}$ & $\begin{array}{c}\text { Negative } \\
\text { Ranks }\end{array}$ & 0 & 0,00 & 0,00 & \\
\cline { 3 - 6 } & & $\begin{array}{c}\text { Positive } \\
\text { Ranks }\end{array}$ & 16 & 8,50 & 136,00 & $-3,520$ & 0,00 \\
\cline { 2 - 6 } & & Total & 16 & & \\
\hline
\end{tabular}

In the chart above data received from pre-test and post-test of experimental group, which were educated with context based vocabulary teaching method, are given. There are the levels of vocabulary knowledge; in pre-test before practicing the method and in post-test after practicing the method. The marks that were taken at pre and post-tests were analyzed with Wilcoxon Signed Ranks Test to judge groups on their own merits. According to this, there isn't observed negative mean rank in experimental group which had 16 participants. In other words, the post-test marks of all participants are higher than pre-test marks. Group's mean rank is 8,50 and sum of sequence values is 136 . As $p=0,000$, there is a meaningful difference observed between pre-test and post-test results of experimental group. 
Chart3. Comparison of pre-test - post-test results of control group

\begin{tabular}{cccccccc}
\hline \multirow{2}{*}{ Groups } & Tests & Ranks & N & $\begin{array}{c}\text { Mean } \\
\text { Ranks }\end{array}$ & Sum of Ranks & Z & P \\
\hline \multirow{2}{*}{$\begin{array}{c}\text { Control } \\
\text { Group }\end{array}$} & $\begin{array}{c}\text { Post Test } \\
\text { Pre Test }\end{array}$ & Negative Ranks & 1 & 1,00 & 1,00 & & \\
\cline { 3 - 6 } & & Positive Ranks & 15 & 9,00 & 135,00 & $-3,467$ & 0,001 \\
\cline { 3 - 6 } & & Total & 16 & & & \\
\hline
\end{tabular}

In the chart above, there are evaluations of pre-test and post-test results analyzed with Wilcoxon Signed Ranks Test of control group educated with traditional methods. In control group -16 participants -, positive ranks are 15, negative ranks are 1. According to this, the post-test mark of one of 16 participants is lower than pre-test mark while the rest of 15 participants' post-test marks are higher than their pre-test marks. The total of negative ranks' mean rank and the sum of sequence values is 1 . Positive ranks' mean rank is 9 and the sum of sequence values is 135 . As $p=0,001$, there is a meaningful difference observed between pre-test and post-test results of control group. As a result, both groups' marks at post-test were higher than pre-test and both of the groups showed significant differences in themselves. In control group in which students were educated traditionally, 15 of 16 participants got higher marks at post-test than pre-test. The participants in experimental group got higher marks at posttest than pre-test, in the same way. However, the marks of experimental group participants are far higher than participants in control group. Consequently, words that are learned in classes in which contextbased vocabulary teaching method is used are more substantive than the words learned in traditional method classes.

In form 2, there is a graphic developed to make it easier to understand the change in the levels of vocabulary knowledge of experimental and control groups. In the graphic, group's mean, median and standard deviations are given. Mean is division of the sum of values of a group of data by the number of data. Median, after ranging a group of data from smallest to largest or largest to smallest, is just the middle value. If the data is double, median is the average of two data that are on the right and the left of the middle. Standard deviation shows how a set of data differs from average value or how values spread about their average (or how much deviated from average value). (Can, 2018: 34). 
Form2. Change in groups' vocabulary learning levels

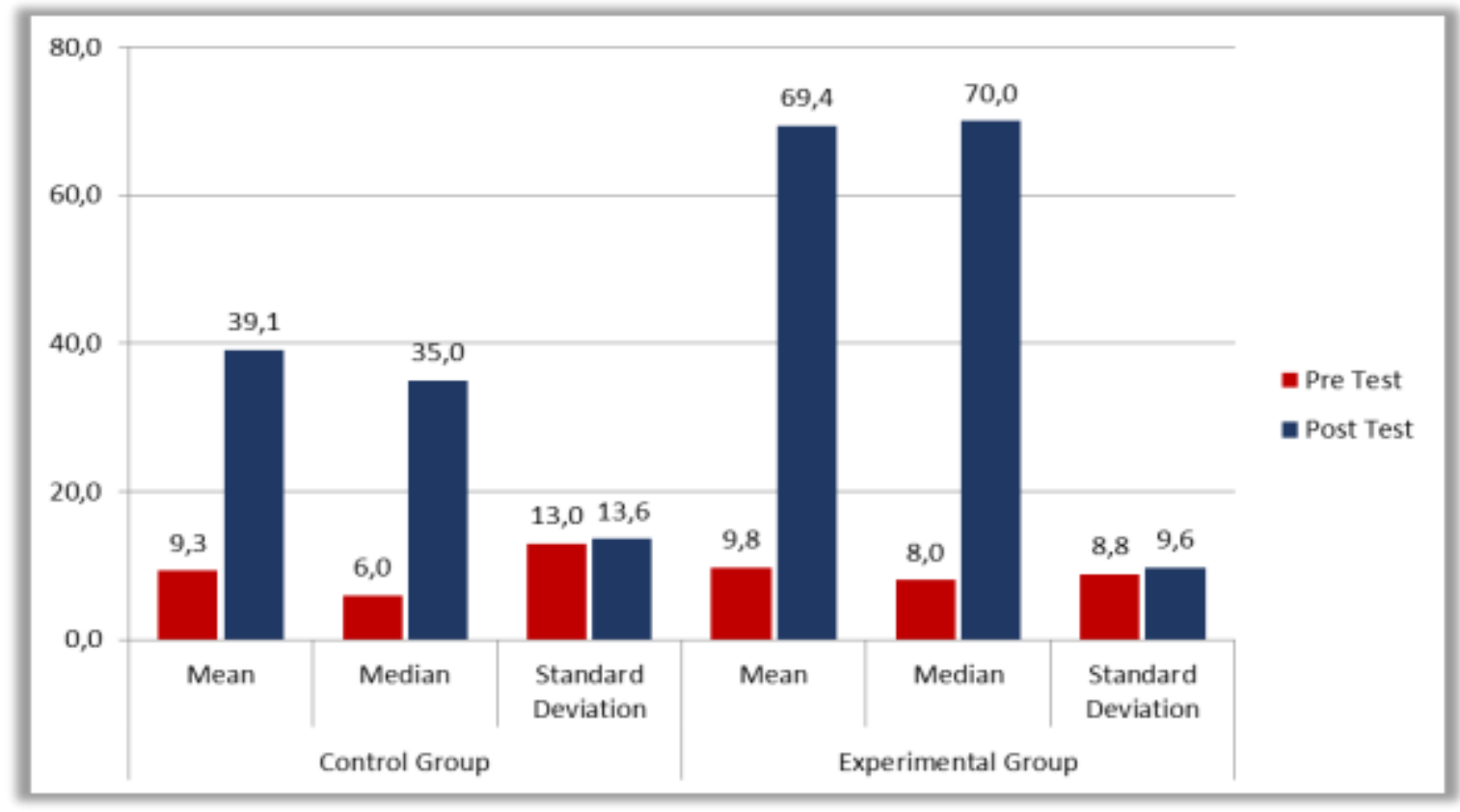

In the graphics above, the average value of control groups pre-test is 9,3 and experimental group's is 9,8. At the beginning both groups are at a close level to each other. While control group's average is 39,1 at the post-test, experimental group group's is 69,4. As seen, experimental group's post-test average is much higher than control group. When looked at median values, control group is 6 in pre-test while experimental group is 8 ; in the post-test control group is 35 and experimental group is 70. Looking at the changes of groups' mean and median values, the development in experimental group's vocabulary learning level is much more than it is in control group. Standard deviation explains how data spread according to arithmetic average. A low standard deviation shows values in a set of data are close to each other, a high standard deviation shows values in a set of data are far from each other. In the graphic above, the standard deviation of control group's pre-test is 13 while it is 13,6 in post-test. In pre-test, the standard deviation of experimental group is 8,8 and it is 9,6 in post-test. The scores of control group's standard deviation are higher than experimental group's. When we look at the scores of groups' standard deviation, we can say that the values of experimental group are closer to each other than control group and the improvement in vocabulary learning levels is more stable.

In the qualitative dimension of the study, the practice sheets that contain the predictions of experimental group participants about the meanings of the new words they encountered in the contextbased vocabulary teaching classes were examined. 20 words were studied on through the research. It was prohibited for participants to look up the dictionaries or any other resources to learn the meaning of them. Under the guidance of the researcher, participants tried to derive the word meanings from the reading text with the help of context clues. Context clues are inscriptive supporters which provide a person to get the meaning of a new word by deducing from the text. They confront readers in a variety of forms. For example, descriptions of an existence or a concept which meanings are unknown help readers to envisage them, these are named descriptive clues. Some words or sentences, which are close (before or after) to new word, are helpful to find its meaning, these are named verbal clues. Life clues are clues which help finding meaning by readers own life observations or experiences. Sometimes when two words are compared with each other or have antonyms, there appear guiding situations related to the meaning of new word; one of these words can be commonly used while the other is unknown. In this way, we benefit from clues of comparison or contradiction. Besides this, there are also synonymous clues. In the text, there are also two words having the same meaning, the known one helps to find the 
meaning of unknown. In summative word clues, the unknown word can be the sum of words mentioned before it. So, a word can be a strong clue for meaning in sentences, too. Besides these, another commonly encountered clue is definition clues. In definition clues, we find the definition of unknown word in the sentence (Öztürk and Otluoğlu, 2001: 48). All these clue types mentioned are helping factors which help reader to find the meaning of new word by using context. In this study carried out by context based vocabulary teaching method, the researcher showed participants various clues from the text and guided them in order to benefit from clues. They mode guesses for meaning of new word by using context clues shown them. It was observed in the examinations about the meaning that 19 of 20 word predictions of participants were predicted correctly. From this point of view, it is possible to say that context-based vocabulary teaching method is an effective way of teaching vocabulary in Turkish instruction as a foreign language.

\section{Conclusion}

In this study, in which the effect of context based vocabulary teaching method on vocabulary learning in teaching Turkish as a foreign language studied, we practiced both quantitative and qualitative research techniques as it is mixed design. The research is an experimental study that has control and experimental groups. Each group consists of 16 B2 level foreign participants who know Turkish. Before implementation, we pre-tested to determine the groups' vocabulary learning level. At first, regarding their CEFR B2 level, we decided on a reading text suitable for participants and 25 new words given mixed and they were asked for matching the new words with their descriptions. As a result of pre-test, the meanings of 5 of 25 words were found to be known, and these words excluded from this study. When the data of pre-test was analyzed with Mann-Whitney U test, it was seen that the vocabulary levels of both experimental group and control group were largely close to each other.

As part of the research, experimental group was instructed with context-based vocabulary teaching method for 4 weeks. Participants tried to find out the meanings of new words by themselves within this period, using the hints in context that the researcher indicated. Control group was instructed traditionally and the words were interpreted by the researcher. The groups made the post-test after 3 weeks in the implementation process that took 4 weeks. Eliminating 5 words which were found to be known in pretest, 20 words were matched with their definitions in the post-test. The data that obtained from post-test were examined with Mann-Whitney $U$ test and it was observed that there was a significant difference between the groups. The research reveals that the vocabulary level of experimental group participants who were instructed with context-based vocabulary teaching method were more extensive than the control group.

The data of pre and post-tests were analyzed with Wilcoxon Signed Ranks Test to judge the vocabulary learning level of the groups on their own merits. The result of the analyses shows that both experimental and control groups had improvement in vocabulary, but the improvement of experimental group was far bigger. Hence it is deduced that context-based vocabulary teaching method is a considerably effective technic for B2 level foreign students learning Turkish vocabulary.

In the implementation of context-based vocabulary teaching method, it was studied especially with B2 level participants, owing to the fact that one needs to have a fund of knowledge of both the grammar and vocabulary of the mentioned language to learn the words by deriving meanings from context. By reason of that, context-based vocabulary teaching method is an effective way for intermediate or upperintermediate level students.

It is observed in the study on deriving word meaning from context that participants have an active role in process with the help of both of them finding clues in text and the researcher referring them. The 
learning becomes more substantive if one finds out the meaning with his/her own personal effort and it takes shape with the person deriving word meaning from context. New words are easier to bear in mind when they are derived from context, also the students gain ability to observe the connection among the words in sentence.

Vocabulary teaching in foreign language education is a field as important as reading, writing, speaking and listening skills but there are not enough researches about this topic. Vocabulary teaching must be dwelled on carefully in teaching Turkish as a foreign language. All in all, the teaching of a language is not composed of only the grammar rules. If one who has been learning a foreign language lives in the country where the mentioned language is the native language, s/he will often encounter plenty of new words in daily life. To learn those words, S/he should take the advantage of context by using his/her fund of knowledge and not looking up a dictionary very often. This study made a contribution to the field of teaching Turkish as a foreign language by revealing that context-based vocabulary teaching method is an effective way in vocabulary education of intermediate level students.

\subsection{The suggestions can be ordered with reference to the data of the study}

1. Vocabulary teaching has an essential place in instruction of Turkish as a foreign language. Therefore, level of intermediate and upper-intermediate books must include activities that are consonant with context-based vocabulary teaching method.

2. Due to the fact that deriving word meaning from context implementation requires one to have knowledge about the grammar and vocabulary of the target language, the method is not suitable for the learners in basic level. In consequence, it should be practiced with intermediate and upper-intermediate level learners.

3. In teaching Turkish as a foreign language, learners should avoid looking up a dictionary straightaway. They should try to derive the meaning by taking the advantage of context firstly and they need to be encouraged for this.

4. In Turkish, not each word is limited to one meaning. They may gain different meanings according to the sentence in which they were used. For instance, the verb "to break" gains different meanings in

* A button of my shirt got "broken" (A button fell off my shirt)

* The robot's arm "broke" (The robot's arm was detached)

* An uproar "broke" in the street (Someone started an uproar in the street)

* My aunt "broke" from our family (My aunt drifted away from our family)

* My wrists are "broken" (My wrists ache so badly) examples.

That is why the word meaning cannot be imagined separated from context. It requires student to understand what s/he reads for him/her to make a deduction about the meanings of unknown words. For this reason teacher must not tell the meaning in a hurry, s/he should guide the students when they need help to comprehend the text. The knowledge which came from the teacher directly will not be permanent, the student's personal performance is more important in sustainability of information.

5. Context clues are assistant elements that lead the reader to finding out the meaning of new words. These may become summarizer clues, definition clues, comparison/contradiction clues, experience clues, contextually etc. Texts that are prepared to teach Turkish to foreigners should represent the Turkish culture on one hand, and include context clues for readers to explore the meanings of unknown words by themselves on the other hand. 
6. For vocabulary to be improved, student must participate in process actively. Thus the meaning gets substantive in the mind of person who tries to learn it with his/her own working so teachers must ensure the proper and active attendance of the students in the lessons.

7. For context-based vocabulary teaching method to be effective teachers must have the ability to show the clues to students and guide the students if necessary and this situation requires teachers to be well equipped.

8. One needs to read a lot in target language to discover the meaning of a new word by availing the context. The more a person who is learning Turkish as a foreign language reads in Turkish, the more informed s/he will get in syntaxes, forming sentences, vocabulary and sentence structure in Turkish and the easier s/he will derive the word meanings from context.

9. It must be taken care of the visual richness of the classes in which Turkish is being taught as a foreign language. Pictures that are related to the present topic should be shown on panel (Turkish cuisine, handicrafts, sports, national and religious holidays, etc.).

10. For context-based vocabulary teaching method to be practiced, these technics can be replaced in lessons: question and answer teaching method, vocabulary teaching via videos, vocabulary teaching with games, vocabulary teaching with reading and listening activities. Because the usage of body language is effective in these technics, teachers must avail their body language fitting the purpose in lessons.

\section{References}

Bora, F. D. (2013). The effect of using contextual vocabulary learning strategies on developing productive vocabulary knowledge of university preparatory class students. Unpublished Master's Thesis, Gazi University Institute of Education Sciences, Ankara.

Büyüköztürk, Ş., Kılıç Çakmak, E., Akgün, Ö. E., Karadeniz, Ş. \& Demirel, F. (2013). Scientific research methods. Ankara: Pegem Academy.

Can, A. (2018). Quantitative data analysis with SPSS in the process of research. Ankara: Pegem Academy.

Demir, A. \& Açık, F. (2011). Multicultural approach in teaching Turkish as a foreign language and characteristics of the texts to be chosen. Turcology Researches Magazine, 30(2), 51-72.

Duran, E. \& Bitir, T. (2017). The effect of context-based instruction method on learning vocabulary. International Education Sciences Magazine, 11, 70-94.

Erdem, M. D., Gün, M., Şengül, M., Şimşek, R. (2015). Consideration of reading texts used in teaching Turkish to foreigners within the context of the common European framework of reference for languages by instructors. Turkish Studies - International Periodical for the Languages, Literature and History of Turkish or Turkic, Volume 10/3 Winter, 2015, p. 455-476, ISSN: 1308-2140, DOI: http://dx.doi.org/10.7827/TurkishStudies.8020.

Göçer, A. (2015). Context-based vocabulary teaching in the process of text manipulation in Turkish main course and the functions on composing effective vocabulary. Native Language Education Magazine, 3(1), 48-63.

Gür, T. (2014). Usage of context-based instruction in vocabulary teaching to $3^{\text {rd }}$ grader students. International Turkish Education Sciences Magazine, 2(2), 242-253. 
Hycraft, J. (1997). An introduction to English language teaching. Malaysia: Longman

İnce, B. (2013). Basic and general principles of foreign language teaching. In Durmuş, M. \& Okur, A. (Eds.), In Turkish instruction for foreigners guidebook (pp.143-156). Ankara: Grafiker Publishing.

Karatay, H. (2004). Consideration of primary school $2^{\text {nd }}$ grade Turkish main course books by means of vocabulary teaching. Master's Thesis, Gazi University Institute of Education Sciences, Ankara.

Memiş, M. R. \& Erdem, M. D. (2013). Methods used, utilization features and critiques on teaching foreign language. Turkish Studies - International Periodical for the Languages, Literature and History of Turkish or Turkic, Volume 8/9 Summer 2013, p. 297-318, ISSN: 1308-2140, DOI: http://dx.doi.org/10.7827/TurkishStudies.5089.

Ortapişirici, Z. (2007). A comparative study of the meaning-given method and meaning-enferred method on rettention in teaching vocabulary at school of foreign languages at Selçuk University. Unpublished Master's Thesis, Selçuk University Institute of Social Sciences, Konya.

Öztürk, C. \& Otluoğlu, R. (2001). Improvement of vocabulary. In Özer, B. (Ed.), In Instruction of Turkish Language and Literature (pp. 212-227). Ankara: Pegem a Publishing.

Söylemez, A. S. (2001). Teaching vocabulary in context. Unpublished, Abant İzzet Baysal University Institute of Social Sciences, Bolu.

Tanın, R. (2004). Instruction and knowledge of vocabulary in teaching Turkish as a foreign language. Master's Thesis, İstanbul University Institute of Social Sciences, İstanbul.

Uzdu Yıldız, F. (2013). Vocabulary and instruction of vocabulary. In Durmuş, M. \& Okur, A. (Eds.), In Turkish Instruction for Foreigners Guidebook (pp.357-379). Ankara: Grafiker Publishing.

Yaman, H. \& Akkaya, D. (2012). The gate of grammar to word species: context types. Turkish Studies - International Periodical for the Languages, Literature and History of Turkish or Turkic. Volume 7/3 Summer 2012, p. 2599-2610, ISSN: 1308-2140, DOI: http://dx.doi.org/10.7827/TurkishStudies.3478.

\section{Bağlam temelli sözcük öğretim yönteminin yabancılara türkçe öğretiminde uygulanmas1}

\section{$\ddot{O} \mathbf{z}$}

Yeni bir dil öğrenmenin temelinde kişinin kendini o dilde iyi ifade edebilmesi ve yine o dilde söylenenleri ya da yazılanları anlayabilmesi bulunmaktadır. Bu sebeple kişinin yabancı dilde etkili bir iletişim kurabilmesi için sözcük dağarcığının zengin olması gerekmektedir. Dolayısıyla sözcük bilgisinin yabancı dilde oldukça önemli bir yeri vardır. Bu çalışmada Türkçenin yabancı dil olarak öğretiminde bağlam temelli sözcük öğretim yönteminin uygulamadaki etkisi incelenmiştir. Bunun için B2 seviyesindeki katılımcılardan oluşan deney ve kontrol gruplarıyla çalışılmıştır. Kontrol grubuyla geleneksel yöntemle ders işlenirken, deney grubuyla bağlam temelli sözcük öğretim yöntemiyle ders işlenmiştir. Çalışma, nitel ve nicel araştırma yöntemlerinin birlikte kullanıldığı karma desenli bir araştırmadır. Nitel çalışmalarda katılımcıların, sözcüklerin anlamlarına ilişkin tahminlerinin yer aldığı cümleler üzerinde doküman analizi yapılmıştır. Araştırmanın nicel boyutunda ise deneysel çalışma 
yapılmıştır. Gruplara ön test ve son test uygulanmıştır. Grupların kelime öğrenim seviyelerini karşılaştırmak için yapılan ön test ve son test verileri Mann Whitney-U Testi ile, her iki gruptaki değişimi kendi içinde değerlendirmek için de Wilcoxon İşaretli Sıralar Testi ile analiz edilmiş̧ir. Ön testte her iki grubun birbirine yakın seviyelerde olduğu, son testte de deney grubundaki sözcük kazanımının kontrol grubundan çok daha yüksek olduğu görülmüş̧ür. Araştırmanın sonunda bağlam temelli sözcük öğretim yönteminin Türkçenin yabancı dil olarak öğretiminde sözcük öğrenimi üzerinde etkili bir yöntem olduğu sonucuna ulaşılmıştır.

Anahtar sözcükler: Bağlam temelli sözcük öğretim yöntemi; yabancı dil olarak Türkçede sözcük öğretimi; sözcük dağarcı̆̆ı.

\section{AUTHOR BIODATA}

Neşe KARA ÖZKAN completed her master's degree in teaching Turkish as a foreign language at Gazi University. She is also a PhD student at the same department. She has been working as a Turkish teacher since 2005. Her interest areas are teaching Turkish and teaching Turkish as a foreign language.

Muammer NURLU, is a professor in the field of Turkish Education at Gazi University. He completed his $\mathrm{PhD}$ degree at Sorbonne University in comparative linguistics (Turkey Turkish-French) in 1996. He completed his first master's degree at Selçuk University, French Language and Literature in 1990, and the second master's degree at Sorbonne University in comparative linguistics (Turkey Turkish-French), 1993. His interest areas are Turkish language, teaching Turkish as a foreign language, linguistic, sociology, French literature. 